\title{
GEOSPATIAL TECHNIQUES USE FOR ASSESSMENT OF VULNERABILITY TO URBAN FLOODING IN BUJUMBURA CITY, BURUNDI
}

\author{
E. Niyongabire ${ }^{1, *}, \mathrm{H}$. Rhinane ${ }^{1}$ \\ ${ }^{1}$ Faculty of Sciences, University Hassan II of Casablanca, Morocco - naleummesig@gmail.com, h.rhinane@gmail.com
}

KEY WORDS: Urban flooding, Vulnerability Index, AHP, WLC, Bujumbura, Burundi

\begin{abstract}
:
The rate of urbanization growth in tropical areas, particularly in African cities, coupled with a gap in the knowledge of vulnerability and coping capacities increases the flood-related risk in diverse communities. This study aims to evaluate the factors of vulnerability to flooding and to develop a vulnerability index in Bujumbura city, Burundi. To this end, both physical and socio-economic parameters accountable for flood vulnerability have been integrated with a geospatial analysis process based on the Analytic Hierarchy Process (AHP) and Weighted Linear Combination (WLC) methods. The resulting vulnerability index shows that lowincome households and their local infrastructures are the most vulnerable to flooding. Another finding reveals that higher vulnerability is due to settlements located in flood-prone areas with unplanned land use and ill-structured development planning.
\end{abstract}

\section{INTRODUCTION}

Globally, urban floods are one of the most common and widely distributed natural hazards and usually trigger from an extreme rainfall which results in an excess of runoff above the capacity of the drainage systems (Adetunji and Oyeleye, 2013). Given the fact that societal assets are often located in areas exposed to natural hazards, vulnerability assessment enhances hazard mitigation and comprehensive planning (Frazier et al, 2014). Recent studies show that various disciplines in hazards research have focused on issues associated with risk and vulnerability (Blaikie et al., 1994; Cutter et al., 2000; Jaeger et al., 2001; Kunreuther, 1998).

In vulnerability literature, there is a distinction between physical and social vulnerability, and both biophysical and socioeconomic variables have been used in flood vulnerability studies (e.g., Clark et al., 1998; Kazmierczak and Cavan, 2011; Kienberger, 2012). Throughout studies on vulnerability, approaches differ and definitions vary from one author to another. Reviews of different concepts and classifications of vulnerability have been carried out by Adger (2006) or Fussel (2007). For example, Clark et al. (1998) considered both physical and social aspects to define vulnerability as 'people's differential incapacity to deal with hazards, based on the position of groups and individuals within both the physical and social worlds' whereas Wisner et al. (2004) were interested in social vulnerability and defined it as the 'the characteristics of a person or group and their situation that influence their capacity to anticipate, cope with, resist and recover from the impact of a natural hazard'.

Earlier studies on vulnerability assessments used to focus on the physical vulnerability (PV) which considers the physical properties of a hazard and features of the natural and built environment. Physical vulnerability refers to the properties of physical structures that determine their potential damage in case of a disaster event (Ebert et al., 2009). Thus, variables of vulnerability can include geomorphologic features (e.g., slope, elevation, or land use/cover), the hydrologic variables such as the amount of rainfall or flood duration, and the built area characteristics (e.g., material type and construction quality).

Due to the unequal impact on exposed populations within a population based on their localities and population subgroups, researchers (e.g. Bates and Peacock, 1987; Bolin, 1986; Bolin and Bolton, 1986; Cutter, 1996) discovered the existence of social and economic forces which contribute to a hazardous event impact and from which stems the concept of social vulnerability (SV). Social vulnerability is a multidimensional concept given that it can reflects various indicators such as poverty (e.g., Fothergill and Peek 2004), race, ethnicity and socioeconomic status (e.g., Bolin, 2006; Peacock et al., 2000), gender (Enarson, 2007), age (Ngo, 2001), income and material resources (Bolin and Bolton, 1986; Bolin and Stanford, 1991) access to insurance (Peacock and Girard, 1997), etc. Some researchers have proved the importance of a combined use of both social and physical variables as they are intrinsically linked (Clark et al., 1998; Rashed and Weeks, 2003).

The recent advances in geospatial techniques show that both biophysical variables and socioeconomic data can be integrated into a geographic information system (GIS) to assess social vulnerability (Ebert et al., 2009; Forte et al., 2006; Meyer et al., 2009; Rashed et al., 2007) .The main objective of this study is to evaluate the physical and social indicators of vulnerability in the local context of urban flooding in Bujumbura and to develop a vulnerability index.

\section{STUDY AREA, DATA AND METHODOLOGY}

\subsection{Study area: Bujumbura city}

Located in East Africa region in Burundi, Bujumbura city, also called 'Bujumbura Mairie', is situated within latitudes $3^{\circ} 18^{\prime}$ $11^{\prime \prime} \mathrm{S}$ and $3^{\circ} 29^{\prime} 8^{\prime \prime} \mathrm{S}$ and longitudes $29^{\circ} 17^{\prime} 16^{\prime \prime} \mathrm{E}$ and $29^{\circ} 25^{\prime}$ 32" E, WGS84. The city grew from 168368 inhabitants in 1979 to 235440 in 1990 and 497166 in 2008 (ISTEEBU,

\footnotetext{
* Corresponding author: Emmanuel NIYONGABIRE (naleummesig@gmail.com)
} 
2008). Its growth follows simultaneously the northern and southern directions knowing that the eastern and western borders are limited respectively by steep mountains and Lake Tanganyika.

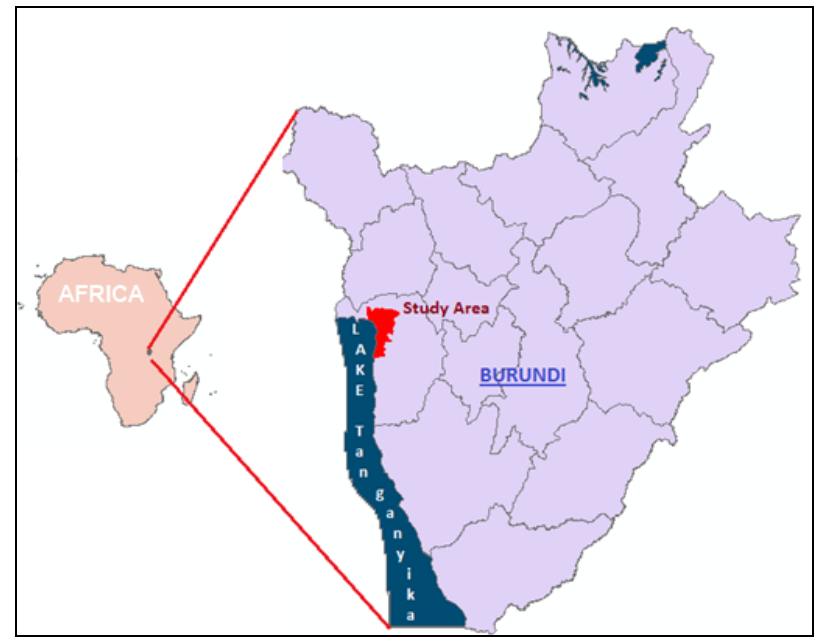

Figure 1. Study area location

Apart from its location in a floodplain, Bujumbura vulnerability to flooding can be imputed to heavy rainfall as the triggering factor. After consecutive days of precipitations, soil is saturated, infiltration is quasi-absent and therefore the runoff increases. The chart in Figure 2 depicts the seasonality of rainfall and explains why most flood events are recorded between December and April.

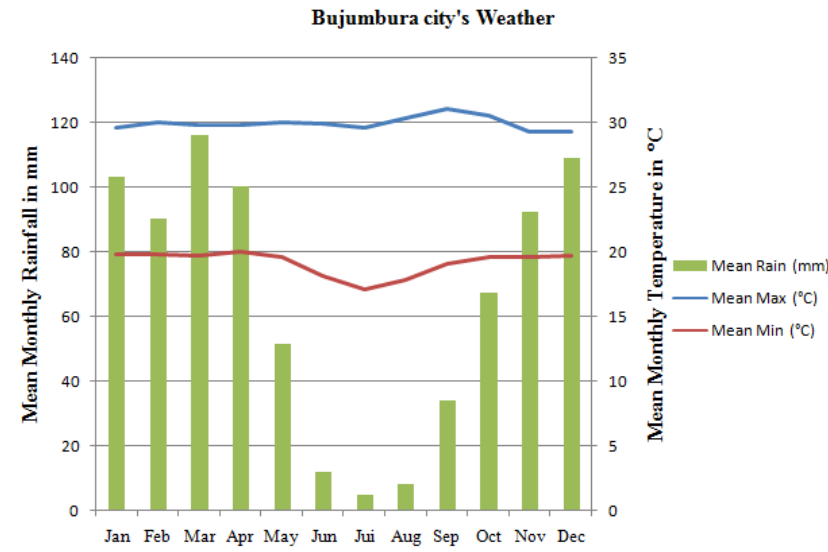

Figure 2. Mean rainfall and mean minimum and maximum temperatures in Bujumbura during 1984-2013

\subsection{Input data}

Data from various sources have been collected in order to retrieve both physical and socio-economic factors of vulnerability. The BCG (Bureau de Centralisation Géomatique du Burundi) provided a Digital Elevation Model (10m DEM) and a $50 \mathrm{~cm}$ orthophoto, both acquired in 2012. A layer of the main rivers which flow across Bujumbura city into Lake Tanganyika was obtained from IGEBU (Institut Géographique $\mathrm{du}$ Burundi). Free Landsat imagery from NASA (https://glovis.usgs.gov) from 1984 to 2017 has been used to evaluate the urban growth and land cover variability. The monographs of the municipalities of the city and field observations helped to assess the housing quality and drainage systems for flood or rain water canalization and the location of health services. Demographic data were based on the population census of 2008 with the estimation for 2012 from ISTEEBU (Institut de Statistiques et d'Etudes Economiques du Burundi).

\subsection{Methodology description}

In vulnerability assessment, the number of variables differs from one study to another. The availability of data, scale of analysis and extent of the study area are decisive factors for any project aiming to derive vulnerability (Fekete et al., 2010). Frequently, the lack of adequate and precise data hinders, in developing countries, the implementation of well-developed methods that are working in developed nations (Dewan, 2013). In the study area, a number of indicators such as economic indicators are usually lacking and eight factors of vulnerability have been assessed. Hover, this research exploits existing information to evaluate the locally contextualized factors of vulnerability in Bujumbura city where is located the highest concentration of residential, commercial, industrial, and educational facilities of the country.

2.3.1 Physical indicators: Four variables have been taken in account: (1) Elevation: low-lying lands are more hazardous and residing populations and infrastructures are more exposed to floods (Dewan, 2013); (2) Distance to channels since proximity to active channel increases the vulnerability (Dewan, 2013); (3) Land use/ land cover: Land use or cover is not a negligible indicator of vulnerability given that the potential effects of floods is higher in built-up areas (Dewan, 2013) and (4) Drainage systems : there are not sufficient canalization structures for rain waters in the study area, which is likely to increase vulnerability (Balica et al., 2012).

2.3.2 Socio-economic indicators: These variables are related to population and community characteristics: (1) Population density, age, gender categories can reveal the level of vulnerability (Paul 2010; Cova and Church 1997); (2) Quality of housing is an indicator of household income and can predict locations more likely to be affected by flood damage (Pelling 1991); (3) Road density: roads are helpful for emergency services intervention and post-event relief and recovery (Sanyal and $\mathrm{Lu}$ 2006, 2009; Rasid et al. 2000) and (4) Health services: populations residing near hospitals or health centers are less affected and more resilient as they are able to recover from injuries more quickly (Fekete, 2009).

The methodology used in the paper can be summarized in the following flowchart (Figure 3). It is based on AHP (Analytic Hierarchy Process) and WLC (Weighted Linear Combination) techniques which fit for spatial multi-criteria assessment. In the AHP hierarchical decision model, each indicator or criteria of the upper level can be broken down into sub-criteria. For example, in our case, physical indicators are elevation, distance to channels, drainage systems and land cover. Now, inside elevation indicator, we can have $758-1005 \mathrm{~m}, 1005-1400 \mathrm{~m} .$. sub-criteria as shown in Table 2. Each criteria is compared to others and a relative importance is given using a 9-point system from 1 (when two criteria equally contribute to the objective) to 9 (when one criterion is more important than another to meet the objective). This is called pairwise comparison.

\begin{tabular}{|l|c|c|}
\hline Elevation $(\mathrm{m})$ & $758-1005$ & $1005-1400$ \\
\hline $758-1005$ & 1 & 2 \\
$1005-1400$ & $1 / 2$ & 1 \\
\hline
\end{tabular}

Table 1. Example of a pair wise comparison matrix. 
In this table, it means that areas in elevations from $758 \mathrm{~m}$ to $1005 \mathrm{~m}$ are two times more vulnerable than areas in elevations between 1005 and $1400 \mathrm{~m}$. The weight of each criterion, as represented in Table 3 , is computed by normalizing the points in the columns (the value of a cell is divided by the sum of the column to obtain a percent) and by averaging the normalized values in the row of the criterion.

The WLC technique is compatible with GIS multi-criteria analysis. During processing, each criterion is considered a data layer and each indicator cell value is multiplied by the corresponding weight and finally all the weighted layers are aggregated. For further understanding, these techniques are explained in Saaty (1977) and Malczewski (1996).

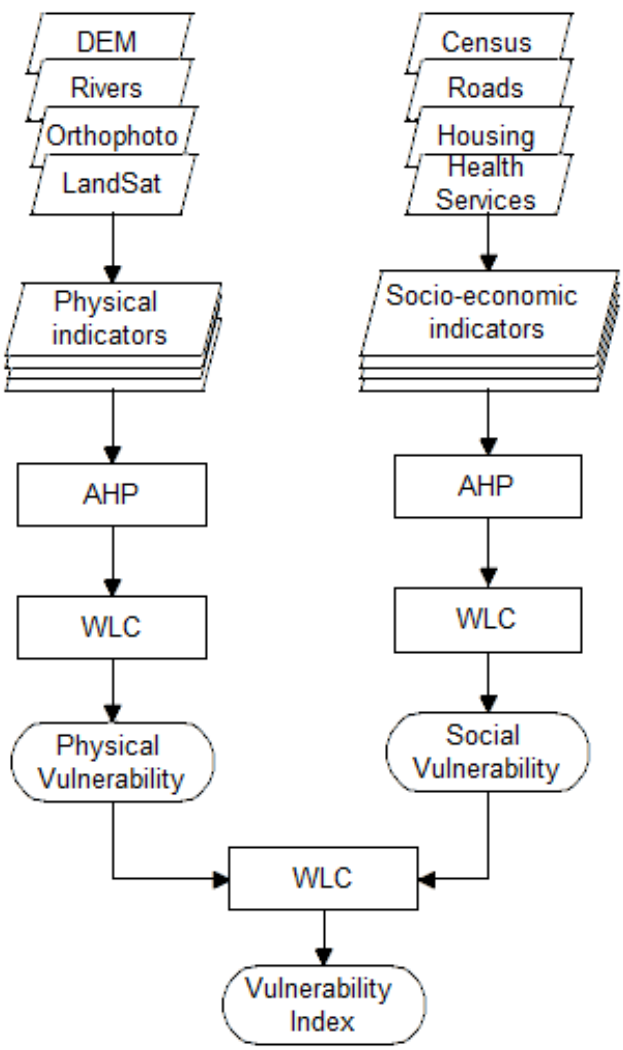

Figure 3. Flowchart of the methodology

Table 3 shows the criteria and their corresponding weights computed using the AHP method.

\begin{tabular}{|l|c|c|c|}
\hline Zones & $\begin{array}{c}\text { House with } \\
\text { sustainable } \\
\text { materials }\end{array}$ & $\begin{array}{c}\text { Houses with } \\
\text { semi-durable } \\
\text { materials }\end{array}$ & $\begin{array}{c}\text { Houses with } \\
\text { poor or very } \\
\text { poor materials }\end{array}$ \\
\hline Buterere & $1 \%$ & $0 \%$ & $99 \%$ \\
Buyenzi & $2 \%$ & $9 \%$ & $89 \%$ \\
Kinama & $5 \%$ & $65 \%$ & $30 \%$ \\
Cibitoke & $30 \%$ & $35 \%$ & $35 \%$ \\
\hline
\end{tabular}

Table 2. The most vulnerable zones due poor quality of housing.

\begin{tabular}{|c|c|c|c|c|c|c|}
\hline & \multicolumn{2}{|c|}{2} & \multicolumn{2}{|l|}{3} & \multicolumn{2}{|l|}{4} \\
\hline & C. & W. & C. & W. & Criteria & Weight \\
\hline \multirow{37}{*}{ 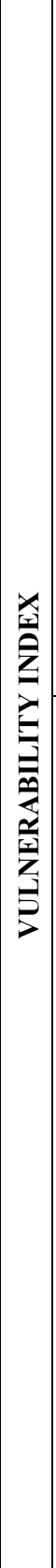 } & \multirow{16}{*}{ 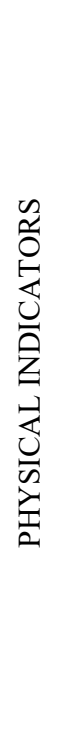 } & \multirow{16}{*}{0,44} & \begin{tabular}{|l|} 
Elevation \\
\end{tabular} & 0,40 & $758-1005$ & 0,49 \\
\hline & & & (m) & & $1005-1400$ & 0,25 \\
\hline & & & & & $1400-1760$ & 0,16 \\
\hline & & & & & $1760-2096$ & 0,09 \\
\hline & & & & & $2096-2664$ & 0,06 \\
\hline & & & Distance & & $0-500$ & 054 \\
\hline & & & to & 0,12 & $500-1500$ & 0,30 \\
\hline & & & channel & & $1500-3000$ & 0,16 \\
\hline & & & (m) & & & \\
\hline & & & Water & 0,28 & Poor & 0,29 \\
\hline & & & drainage & & Limited & 0,15 \\
\hline & & & & & Good & 0,07 \\
\hline & & & & & Built-up & 0,68 \\
\hline & & & & & Farmland & 0,16 \\
\hline & & & Land use & 0,20 & Bare soil & 0,11 \\
\hline & & & & & $\begin{array}{l}\text { Water } \\
\text { bodies }\end{array}$ & 0,05 \\
\hline & \multirow{21}{*}{ 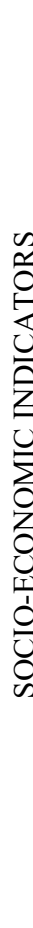 } & \multirow{21}{*}{0,56} & & & Very bad & 0,44 \\
\hline & & & Housing & & $\mathrm{Bad}$ & 0,26 \\
\hline & & & quality & 0,51 & Poor & 0,18 \\
\hline & & & & & Decent & 0,08 \\
\hline & & & & & Good & 0,05 \\
\hline & & & Road & & $0-3$ & 0,41 \\
\hline & & & density & 0,18 & $3-8$ & 0,27 \\
\hline & & & $\left(\mathrm{km} / \mathrm{km}^{2}\right)$ & & $8-12$ & 0,16 \\
\hline & & & & & $12-16$ & 0,10 \\
\hline & & & & & $16-24$ & 0,06 \\
\hline & & & Health & & $0-1.82$ & 0,42 \\
\hline & & & services & & $1.83-3.57$ & 0,26 \\
\hline & & & (per & 0,17 & $3.58-5.44$ & 0,16 \\
\hline & & & 10000 & & $5.45-7.65$ & 0,10 \\
\hline & & & hab.) & & $7.66-11$ & 0,06 \\
\hline & & & & & $15000-$ & 0,44 \\
\hline & & & tion & 0,14 & $7000-$ & 0,27 \\
\hline & & & density & & 15000 & \\
\hline & & & (hab/km²) & & $3000-7000$ & 0,15 \\
\hline & & & & & $1400-3000$ & 0,08 \\
\hline & & & & & $1000-1400$ & 0,05 \\
\hline
\end{tabular}

Table 3. Decision hierarchy model

\section{RESULTS AND DISCUSSION}

\subsection{Physical Indicators}

3.1.1 Elevation: The geomorphologic aspect is the first analysed factor. The entire extension of Bujumbura city is spread over the lowest elevation part of the watershed. Apart from the low topography, the city represents the coastline area along the Lake Tanganyika which has been rising in past and threatening human settlements and activities.

The most historically known Tanganyika rising event was recorded in 1964 during which water level went 4 meters higher and inundated a significant part of the city. It is also important to note that recently, the Lake level increased for more than 2.5 
meters in May 2016. Figure 4 shows that Bujumbura Mairie lays in the elevation from 758 to 1005 meters whereas the steepest areas located eastwardly have elevation that can reach 2 660 meters. Before rain waters enter into urban area, rivers collect them from more than 15 kilometres and the accumulation results in flood occurrence in case of heavy rainfall.

3.1.2 Distance to channels: Six (6) main rivers (namely Mutimbuzi, Nyabagere, Ntahangwa, Muha, Kanyosha, Kizingwe) stem from the eastern mountainous areas to flow into Lake Tanganyika across the city. Areas located close to the rivers and flow accumulation path are more likely to get flooded. According to Figure 6, more than 50 identified buildings from the orthophoto acquired in 2012 are located in a distance of 20 meters. Moreover, spatial analysis shows that 1 797 buildings are found in a distance not exceeding 500 meters.

3.1.3 Land cover and land cover change: As for land cover, three main categories are identified: the built-up area, farmland and vegetation, and bare soil with grass. In 2017, more than 70 percent of Bujumbura Mairie area is built and more than 90 percent of buildings settled in floodplain. Figure 5 depicts the growth of the city based on LandSat imagery between 1984 and 2017 and the Table indicates the estimation of built-up areas for each date. In some zones (such as Cibitoke, Kamenge, Nyakabiga, Buyenzi or Bwiza) that were built before 1984, there are a considerable number of buildings that are worn out because of the poor quality of housing and roofing materials. This makes the dwellers vulnerable to heavy rainfall which can easily destroy houses with deaths and/or population displacement. Other zones such as Buterere suffer from the lack of planning for urban expansion leading to development in areas at risk of flooding and in slums development. Poor urban planning in Bujumbura city plays an important role in vulnerability to flooding. Paradoxally, poor groups with lowincome tend to settle in the most at risk areas. This is the case for Buterere dwellers who live in extremely poor residences exposed to regular flooding of homes. It is of necessity to replace those houses and adapt land planning to the reality of flooding.

3.1.4 Drainage systems: Another factor of vulnerability due to poor land planning is a result of inadequacy of drainage systems. Besides river flooding, in many cases, flood waters exceed the capacity of existing canalizations and flood results. That way, rain water can inundate houses up to 1 meter, which causes damage to belongings of households. In general, pipelines suffer from low quality and sub-capacity compared to rainwater. Figure 7 shows the most vulnerable areas due to the quality or existence of drainage systems.

\subsection{Socio-economic Indicators}

3.2.1 Population density: One of the most important indicators in determining social vulnerability is population density. During and after a flood event, localities with high density face more problems, including evacuation difficulties and increased risk of disease transmission. Figure 12 depicts that ancient zones (Cibitoke, Kamenge, Buyenzi, Bwiza and Nyakabiga) consist in higher population density. Furthermore, majority of the inhabitants in these zones comprises urban poor populations facing a worsening situation because of the increasing frequency of heavy rainfall occurrences.
3.2.2 Quality of house: Vulnerability due to the quality of housing cannot be emphasized given that the quality of a large number of houses in Bujumbura is substandard. Higher vulnerability is exhibited in zones where houses are subject to damage during a flooding event. Frequently, flood event is followed by population displacement due to houses destruction and this happens almost every year. For example, during a flood event occurred on 28th April 2018 especially in Buterere, 3 causalities were recorded, more than 320 houses were destroyed and more than 2500 displaced. Table 2 presents the most vulnerable zones due poor quality of housing and Figure 11 classifies the zones according to the quality of housing from good to very bad.

The classification of houses according to the materials used to build walls shows that $60.1 \%$ are houses made up with adobe bricks, $29.5 \%$ with baked bricks (more sustainable than adobe), $3.1 \%$ with concrete from the mixture of cement and gravel or/and sand, $4.4 \%$ with wood and other materials. This situation needs to change.

3.2.3 Road density: Roads are known as a category of lifeline infrastructure facilities. The road density plays a significant role in evacuation, post-event relief and recovery. Though Buterere is located in the floodplain and near to Lake Tanganyika, it is most the vulnerable zone due to a lower density of roads.

3.2.4 Access to medical services: During heavy rainfall, house damage can be accompanied by injuries and deaths. Populations who have access to medical services are less affected and more resilient as they are able to recover from injuries more quickly. According to Figure 10, medical services are concentrated in Rohero with eight hospital and clinics and four health centers whereas Ngagara has no health center. Consequently, distance to closer hospital increases as we move to peripheral zones in the south and north areas (Figure 9).

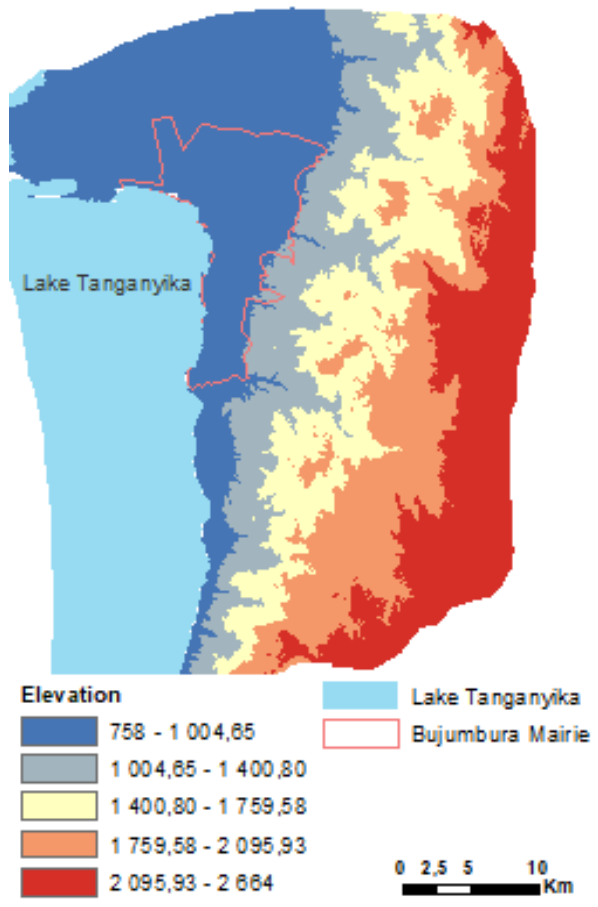

Figure 4. Elevation classes and location of Bujumbura city in the floodplain 


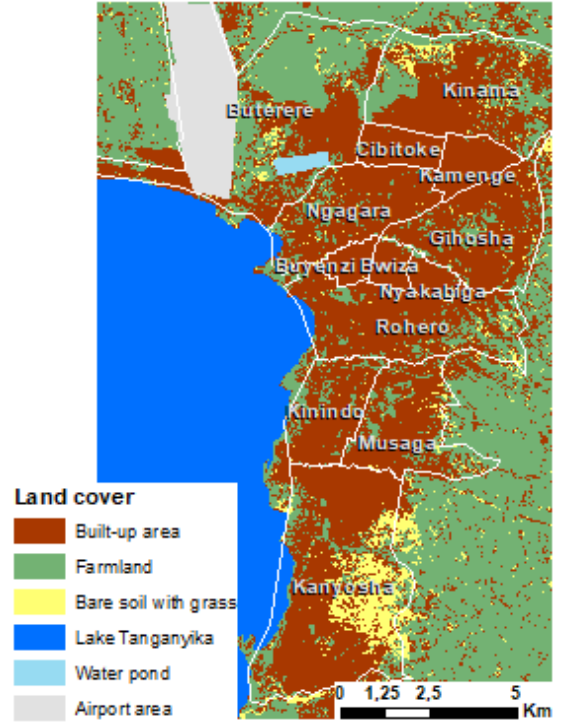

Figure 5. Land cover for 2017 from Landsat imagery

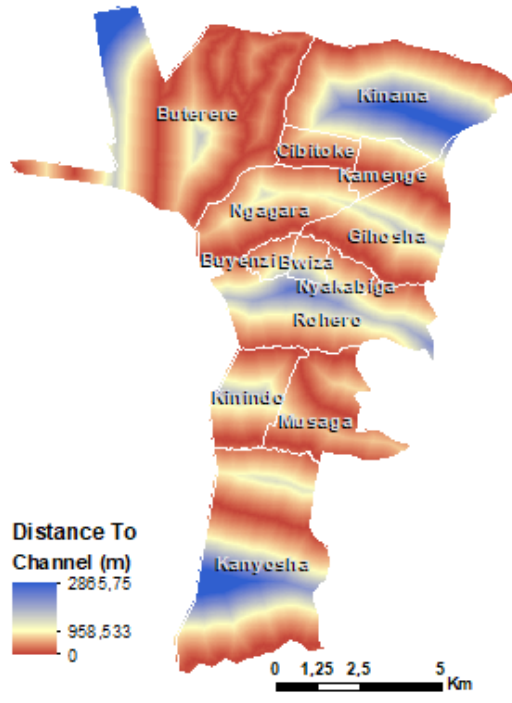

Figure 6. Distance to channels : more than 50 buildings were located in the 20 meters distance to rivers in the North of the city

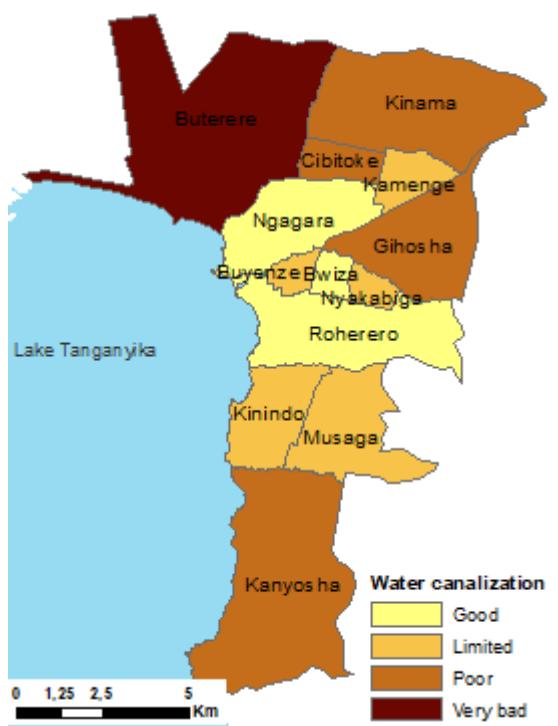

Figure 7. Assessment of rain water drainage systems

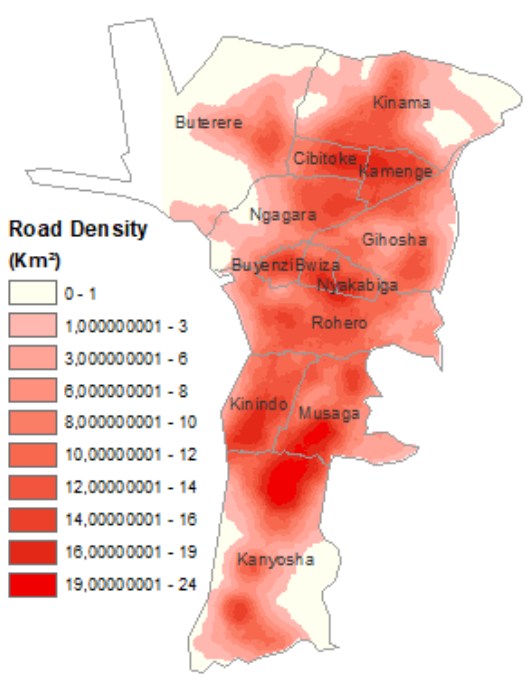

Figure 8. Road density in $\mathrm{Km}$ per $\mathrm{Km}^{2}$

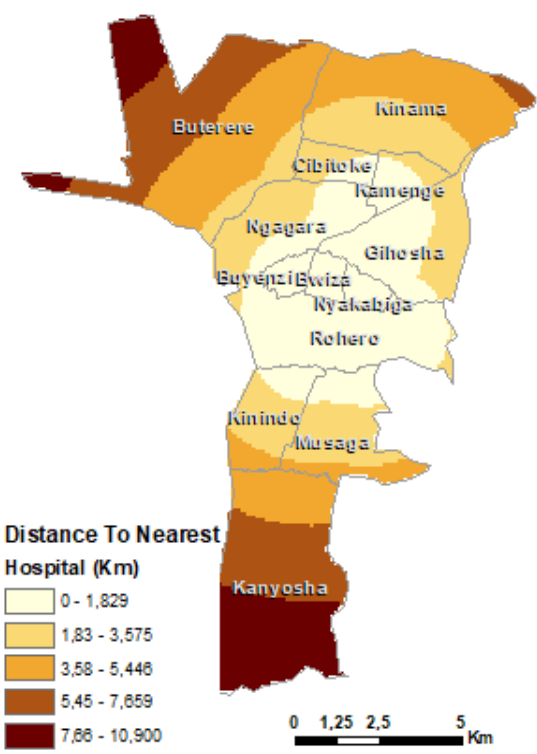

Figure 9. Distance to nearest hospitals

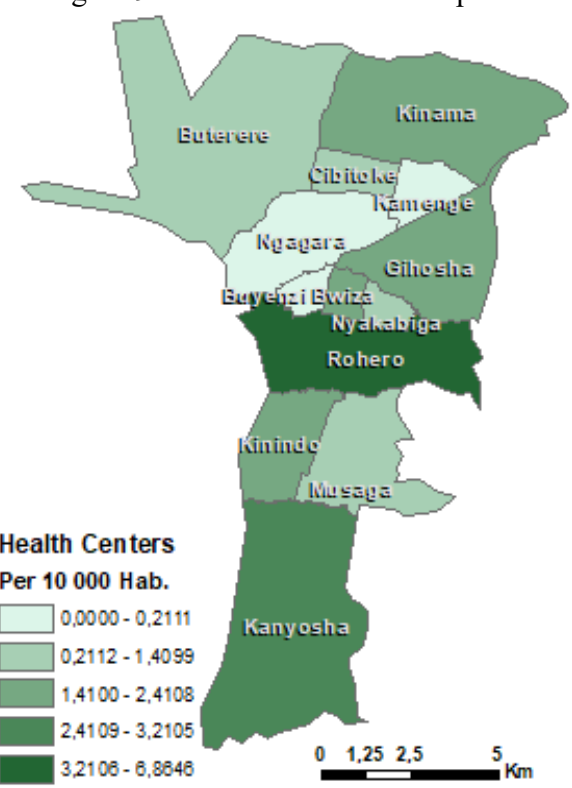

Figure 10. Number of Health Centers by municipality per 10000 habitants 


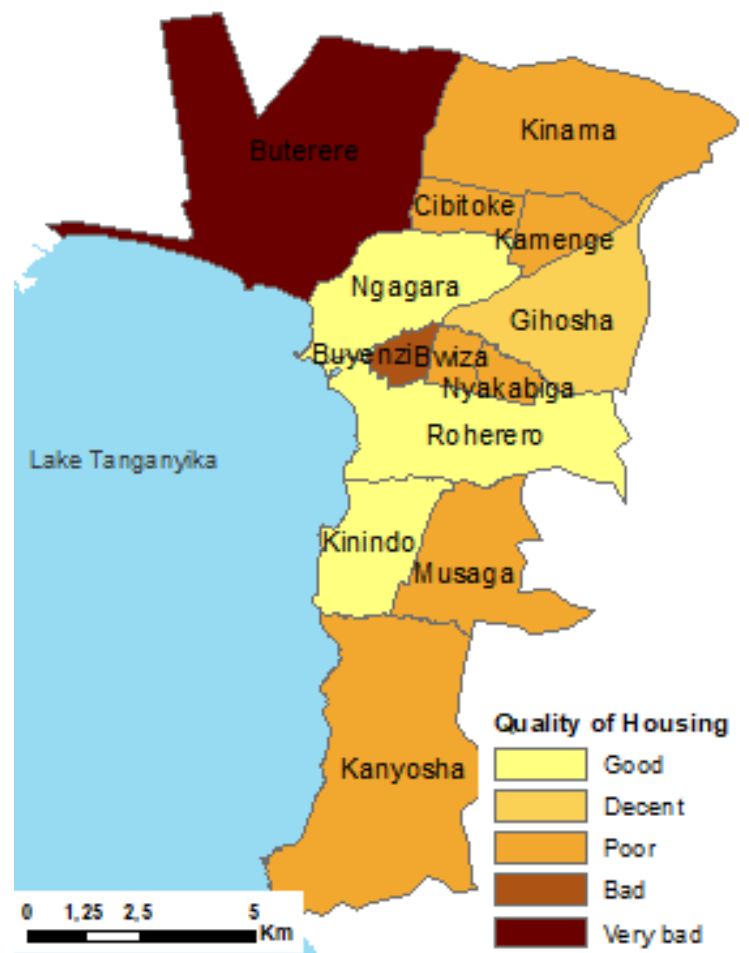

Figure 11. Housing quality in Bujumbura city.

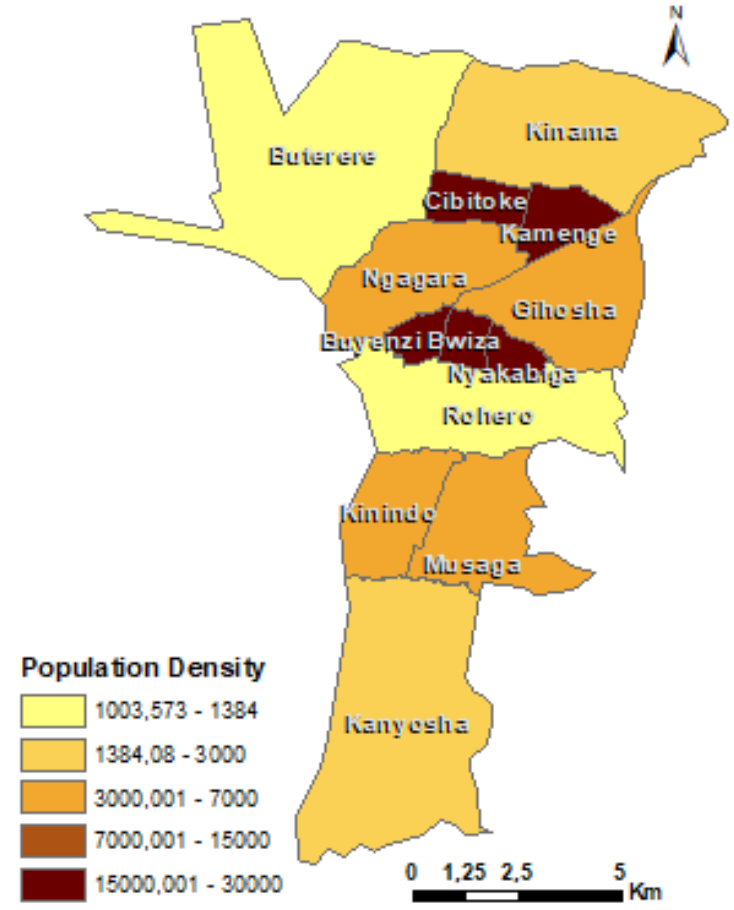

Figure 12 . Population density by municipalities.

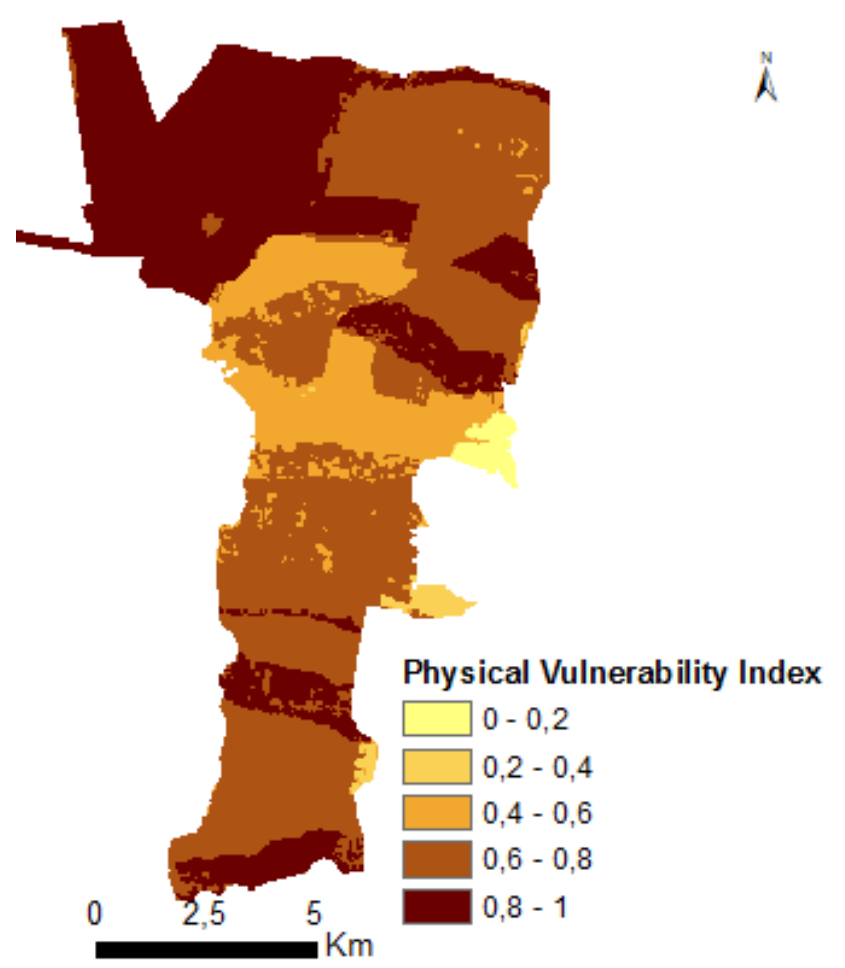

Figure 13. Resulting Physical Vulnerability Index

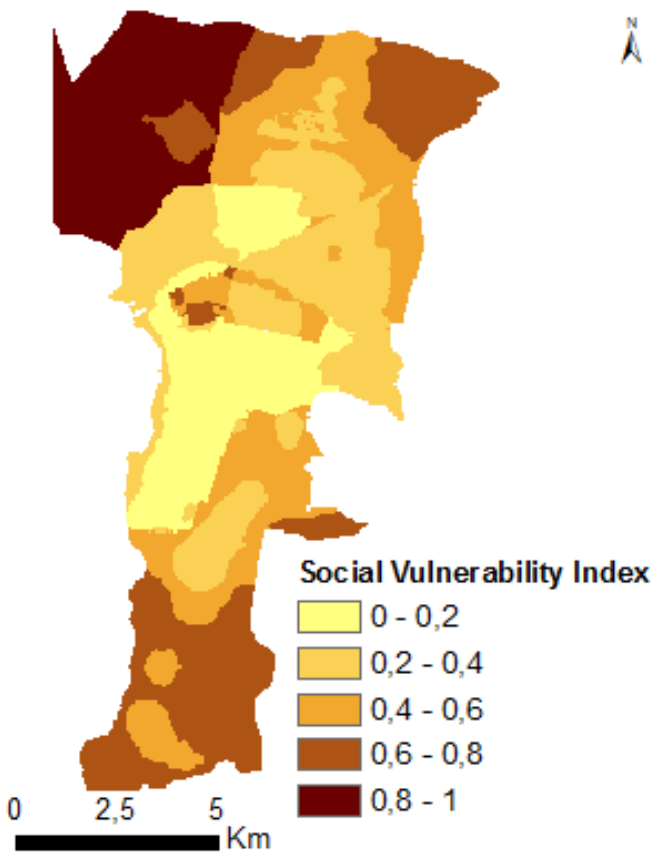

Figure 14. Resulting Social Vulnerability Index. 


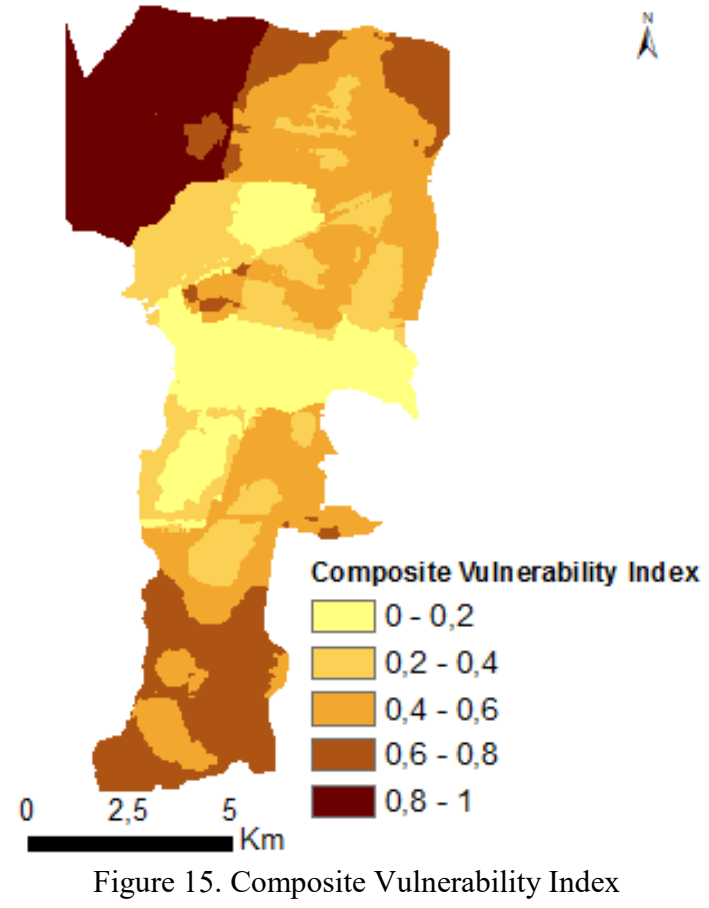

\section{CONCLUSION}

Floods affect the day-to-day lives of the population that belongs to a socio-economic system. In this study, both physical and socio-economic indicators of vulnerability have been analyzed. The results of the present research lead to the understanding that each zone of Bujumbura city can be vulnerable to flooding depending to a given indicator of vulnerability. In terms of exposure, households in both low and higher-income areas are exposed to floods but the exposure can be severe for inhabitants located closer to Lake Tanganyika. The analysis shows that Buterere zone is the most vulnerability to its physical location, poor quality of housing, the lack of infrastructures such roads, medical services and drainage systems. But in general, zones with a good quality of housing (e.g., Rohoro and Kinindo) are less vulnerable as result of the high income of the dwellers, high quality of buildings, road density and near medical services. In every part of the city, flood has occurred in the past with differences in frequency and intensity but capacity to recover makes the most significant difference.

This study demonstrates the fact that the use of geospatial techniques for assessing vulnerability is likely to become a useful tool in disaster risk reduction and monitoring. The spatial analysis can help land use planners and emergency managers in reducing vulnerability and disaster damages. Finally, understanding vulnerability in Bujumbura city in terms of urban planning is profitable to the day-to-day decision-making process.

\section{REFERENCES}

Adetunji, M., Oyeleye, O., 2013. Evaluation of the causes and effects of flood in Apete, Ido Local Government Area, Oyo State, Nigeria. Civ. Environ. Res., 3, pp. 19-26.

Adger, W.N., 2006. Vulnerability. Global Environmental Change, 16(3), pp. 268-281.
Balica, S.F., Wright, N.G. \& van der Meulen, F., 2012. A flood vulnerability index for coastal cities and its use in assessing climate change impacts. Natural Hazards, 64(1), pp. 73-105, https://doi.org/10.1007/s1 1069-012-0234-1

Bates, F.L. and Peacock, W.G., 1987. Disasters and Social Change. In: R.R. Dynes, B. Demarchi and C. Pelanda (eds.) The Sociology of Disasters. Franco Angeli Press, Milan, pp. 291-330.

Blaikie, P., Cannon, T., Davis, I., and Wisner, B., 1994. At risk: Natural hazards, people's vulnerability, and disasters, Routledge, London.

Bolin, R., 1986. Disaster Impact and Recovery: A Comparison of Black and White Victims. International Journal of Mass Emergencies and Disasters, 4(1). pp. 35-50.

Bolin, R. (2006). "Race, class, and disaster vulnerability." In E.L. Quarantelli and R. Dynes (eds.), Handbook of Disaster Research. New York: Springer, pp. 113-129.

Bolin, R. and Bolton, P., 1986. Race, Religion, and Ethnicity in Disaster Recovery. Monograph No. 42. Program on Environment and Behavior, Institute of Behavioral Science, University of Colorado, Boulder, CO.

Bolin, R. and Stanford, L., 1991. Shelter, housing, and recovery: A comparison of U.S. disasters. Disasters, 15, pp. 24 34.

Clark, G.E., Moser, S.C., Ratick, S.J., Dow, K., Meyer, W.B., Emani, S., Jin, W., Kasperson, J.X., Kasperson, R.E., Schwartz, H.E., 1998. Assessing the vulnerability of coastal communities to extreme storms: the case of Revere, MA, USA. Mitigation and Adaptation Strategies for Global Change, 3(1), pp. 59-82, https://doi.org/10.1023/A:1009609710795.

Cova, T.J., Church, L., 1997. Modeling community vulnerability evacuation using GIS. International Journal of Geographical Information Science, 11(8) pp. 763-784, https://doi.org/10.1080/136588197242077.

Cutter, S., 1996. Vulnerability to Environmental Hazards. Progress in Human Geography. 20(4). pp. 529-539.

Cutter, S.L., Mitchell, J. T., and Scott, M.S., 2000. Revealing the vulnerability of people and places: A case study of Georgetown County, South Carolina. Annals of the Association of American Geographers, 90(4), pp. 713-737, https://doi.org/10.1111/0004-5608.00219.

Dewan, A.M., 2013. Floods in a Megacity: Geospatial Techniques in Assessing Hazards, Risk and Vulnerability, Springer Geography, DOI 10.1007/978-94-007-5875-9_6.

Ebert, A., Kerle, N., Stein, A., 2009. Urban social vulnerability assessment with physical proxies and spatial metrics derived from air- and spaceborne imagery and GIS data. Natural Hazards, 48(2) pp. 275-294.

Enarson, E., 2007. Chapter 13: Identifying and addressing social vulnerabilities. In: Waugh, W.L. and Tierney, K. (eds.), Emergency Management: Principles and Practices for Local Government (2nd Ed). Washington D.C.: ICMA Press, pp. 257-278. 
Fekete, A. 2009. Validation of a social vulnerability index in context to river-floods in Germany. Nat. Hazards Earth Syst. Sci., 9, 393-403.

Forte, F., Strobl, R.O., Pennetta, L., 2006. A methodology using GIS, aerial photos and remote sensing for loss estimation and flood vulnerability analysis in the Supersano-RuffanoNociglia Graben, southern Italy. Environmental Geology, 50(4), pp. 581-594.

Fothergill, A., Peek, L.A., 2004. Poverty and disasters in the United States: a review of recent sociological findings. Natural Hazards, 32(1) pp. 89-110.

Frazier, T.G., Thompson, C.M., Dezzani, R.J., 2014. A framework for the development of the SERV model: A Spatially Explicit Resilience-Vulnerability model. Applied Geography, 51, pp. 158-172. http://dx.doi.org/10.1016/j.apgeog.2014.04.004.

Fussel, H., 2007. Vulnerability: a generally applicable conceptual framework for climate change research. Global Environmental Change, 17(2), pp. 155-167.

ISTEEBU, 2008. Recensement Général de la Population et de l'Habitat (RGPH) - Etat et Structure de la Population en 2008 , ISTEEBU, Burundi.

Jaeger, C.C., Renn, O., Rosa, E.A., and Webler, T., 2001. Risk, uncertainty, and rational action, Earthscan Publications, London.

Kazmierczak, A., Cavan, G., 2011. Surface water flooding risk in urban communities: analysis of vulnerability, hazard and exposure. Landscape Urban Plan, 103(2) pp. 185-197.

Kienberger, S., 2012. Spatial modelling of social and economic vulnerability to floods at the district level of Buzi, Mozambique. Natural Hazards, 64(3), pp. 2001-2019. https://doi.org/10.1007/s11069-012-0174-9

Kunreuther, H., and Roth, R.J., eds., 1998. Paying the price: The status and role of insurance against natural disasters in the United States, Joseph Henry Press, Washington, D.C.

Malczewski J., 1996. A GIS-Based Approach to Multiple Criteria Group Decision Making. Geographical Information Systems 10(8):955-971.

Meyer, V., Scheuer, S., Haase, D., 2009. A multicriteria approach for flood risk mapping exemplified at the Mulde river, Germany. Natural Hazards, 48(1) pp. 17-39.

Ngo, E.B., 2001. When disasters and age collide: reviewing vulnerability of the elderly. Natural Hazards Review, 2(2), pp. 80-89.

Paul, B.K., 2010. Human injuries caused by Bangladesh's cyclone SIDR: an empirical study. Natural Hazards, 54(2), pp. 483-495.

Peacock, W. G. and Girard, C., 1997. Ethnic and racial inequalities in hurricane insurance and settlements. In: Peacock, W.G., Morrow, B. H. and Gladwin, H. (eds.), Hurricane Andrew: Ethnicity, Gender, and the Sociology of Disasters.
Miami, FL: International Hurricane Center, Laboratory for Social and Behavioral Research, pp. 171-190.

Peacock, W.G., Morrow, B.H., Gladwin, H., 2000. Hurricane Andrew and the reshaping of Miami: ethnicity, gender, and the socio-political ecology of disasters. Florida International University, International Hurricane Center, Miami, FL.

Pelling, M., 1997. What determines vulnerability to floods: a case study in Georgetown, Guyana. Environment and Urbanization, 9(1), pp. 203-226.

Rashed, T., Weeks, J. 2003. Assessing vulnerability to earthquake hazards through spatial multicriteria analysis of urban areas. International Journal of Geographical Information Science, 17(6) pp. 547-576.

Rashed, R., Weeks, J., Couclelis, H., Herold, M., 2007. An integrative GIS and remote sensing model for place-based urban vulnerability analysis. In: Mesev, V. (ed). Integration of GIS and remote sensing. Wiley, Chichester, pp. 199-224.

Rasid, H., Haider, W., Hunt, L. 2000. Post flood assessment of emergency evacuation policies in the Red river delta, Southern Manitoba. The Canadian Geographer, 44(4), pp. 369-386.

Saaty T.L., 1980. The Analytic Hierarchy Process. McGrawHill, New York.

Sanyal, J., Lu, X.X., 2006. GIS based flood hazard mapping in Gangetic West Bengal. Singap J Trop Geogr 27(2):207-220.

Sanyal J, Lu XX (2009) Ideal location for flood shelter: a geographic information system approach. J Flood Risk Assess 2(4):262-271.

Wisner, B., Blaikie, P., Cannon, T., Davis, I., 2004. At risk: natural hazards, peoples vulnerability and disasters, 2nd edn. Routledge, London. 